\title{
The Holy Spirit and the Church according to the New Testament
}

\author{
Sixth International East-West Symposium of New Testament Scholars, Belgrade, \\ August 25 to 31, 2013
}

Ed. by Predrag Dragutinovic, Karl-Wilhelm Niebuhr, and James Buchanan Wallace in co-operation with Christos Karakolis

[Der Heilige Geist und die Kirche im Neuen Testament. Sechstes Internationales Ost-West Symposium der Neutestamentler, Belgrad, 25.-31. August 2013.]

The Holy Spirit and the Church according to the New Testament

Edited by PREDRAG DRAGUTINOVIC KARL-WILHELM NIEBUHR and JAMES BUCHANAN WALLACE

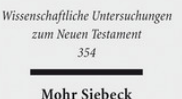

2016. IX, 516 Seiten. WUNT I 354

ISBN 978-3-16-154369-2 DOI 10.1628/978-3-16-154369-2 eBook PDF 174,00€

ISBN 978-3-16-153507-9

Leinen $174,00 €$
Veröffentlicht auf Englisch.

Der Band dokumentiert die Vorträge vom Sechsten Internationalen Ost-West Symposium der Neutestamentler in Belgrad. Diese Symposien gehören zu den Projekten des Eastern Europe Liaison Committee der Studiorum Novi Testamenti Societas. Hauptthema der Aufsätze ist der Heilige Geist in den neutestamentlichen Schriften, besonders im Johannesevangelium, im lukanischen Werk und bei Paulus, außerdem die Rezeption solcher biblischen Aussagen in der patristischen Theologie, der altkirchlichen Liturgiegeschichte und der Ikonographie. Beiträge aus den Seminaren behandeln außerbiblische frühjüdische und frühchristliche Texte. Alle Themen werden sowohl aus »westlicher « (protestantischer und katholischer) als auch aus orthodoxer Perspektive behandelt. Eine Einführung skizziert die aktuelle neutestamentliche Forschung zum Thema und verweist auf Texte und Fragestellungen, die im Band nicht ausdrücklich behandelt werden.

Inhaltsübersicht

Karl-Wilhelm Niebuhr: Introduction

I. Biblical Scholarship in Serbia

Bishop Irinej Of Novi Sad And Bachka: The Holy Spirit and the Church. An Orthodox Perspective - Vladan Tatalović : Orthodox New Testament Scholarship in Serbia

II. Papers from the Symposium

N. T. Wright: The Glory Returns: Spirit, Temple and Eschatology in Paul and John - Christos Karakolis: The Holy Spirit in LukeActs: Personal Entity or Impersonal Power? A Synchronic Approach - Danie/ Marguerat: The Work of the Holy Spirit in LukeActs: A Western Perspective - Predrag Dragutinović: The Holy Spirit and the Church in the Gospel of John. A Discourse Analysis of John 20:19-23 - Andreas Dettwiler: The Holy Spirit in John from a Western Perspective - John Fotopoulos: The Holy Spirit in Paul from an Orthodox Perspective - Volker Rabens: The Holy Spirit and Deification in Paul: A 'Western' Perspective Demetrios Bathrellos: The Holy Spirit and the New Testament in St. Symeon of Thessalonica (†1429) - Katharina Bracht: Augustine and His Predecessors Interpreting the New Testament on the Origin of the Holy Spirit. The Question of filioque Harald Buchinger: The Holy Spirit and the Church in Liturgy. A »Western Perspective«

III. Contributions from the Seminars

The Holy Spirit in Ancient Judaism

Rodoljub S. Kubat: The Spirit in the Wisdom of Solomon and its Old Testament Background - James Buchanan Wallace: Spirit(s) in the Testaments of the Twelve Patriarchs - Carl R. Holladay : Spirit in Philo of Alexandria

The Holy Spirit and the Church in the Gospels

Armand Puig / Tàrrech: Holy Spirit and Evil Spirits in the Ministry of Jesus - Joe/ Marcus: The Spirit and the Church in the Gospel of Mark

The Holy Spirit and the Church in Second Century Christian Writings

Tobias Nicklas: A Church without Spirit? Pneumatology in the Writings of Ignatius of Antioch - Taras Khomych: From Maranatha to Epiclesis? An Inquiry into the Origins of Spirit Invocations in Early Christianity

\section{Reflections}

Manuel Vogel: A Talk Continued. Notes and Deliberations on the Belgrade Conference - Ekaterini Tsalampouni: A Reflection on the Conference from the Orthodox Perspective - Armand Puig / Tàrrech: A Reflection on the Conference from a Catholic Perspective

Appendix

Oksana Gubareva: The Holy Spirit in Orthodox Iconography

Predrag Dragutinović Born 1972; since 2008 Lecturer for the New Testament at the Faculty of Orthodox Theology, University of Belgrade; since 2014 Associate Professor for New Testament and head of the Biblical Institute in Belgrade, and Research Associate in New Testament, Faculty of Theology, Stellenbosch University, South Africa.

Karl-Wilhelm Niebuhr Geboren 1956; 1986 Promotion; 1991 Habilitation; 1994-96 Professor für Biblische Theologie 
(evangelisch) an der Technischen Universität Dresden; 1997-2022 Professor für Neues Testament an der Friedrich-SchillerUniversität Jena; Präsident des Eastern Europe Liaison Committee (EELC) der Studiorum Novi Testamenti Societas (SNTS). https://orcid.org/0000-0002-8850-7046

James Buchanan Wallace Born 1975; 1994-98 studied at Sewanee (The University of the South); 1998 BA in English Literature and Russian; 1998-2008 studied Theology/New Testament at Emory University Atlanta; 2002 M.Div.; 2008 PhD in Religion; since 2012 Associate Professor of Religion at Christian Brothers University.

Christos Karakolis Born 1968; 1990 Bachelor in Theology; 1990-96 Doctoral studies at the Universities of Thessaloniki, Regensburg and Tübingen; 1996 ThD; since 2005 Assistant Professor at the Faculty of Theology of the University of Athens.

Jetzt bestellen:

https://mohrsiebeck.com/buch/the-holy-spirit-and-the-church-according-to-the-new-testament-9783161543692?no_cache=1 order@mohrsiebeck.com

Telefon: +49 (0)7071-923-17

Telefax: $+49(0) 7071-51104$ 